\title{
児童の事象関連電位の特徵
}

\author{
金田健 史 ${ }^{1)}$ 西平賀 昭 ${ }^{2)}$ 八田有洋 ${ }^{2)}$ 麓 正 樹 ${ }^{1)}$ \\ 下田 政 博 ${ }^{3)}$ 時任真一郎 ${ }^{1)}$ 秋山幸 代 ${ }^{1)}$
}

\section{FEATURE OF EVENT-RELATED POTENTIALS IN DEVELOPING CHILDREN}

\author{
Takeshi Kaneda, Yoshiaki Nishihira, Arihiro hatta, Masaki Fumoto, \\ Masahiro Shimoda, Sin-ICHIRO TOKITOH and SAChiyo AKIYAma
}

\begin{abstract}
We examined here, changes in event-related potentials (ERPs) in eighteen children from 7 to 12 years and twelve adults. In addition to ERPs, we examined changes of EMG-RT. Subjects performed an auditory target discrimination task, in which $1000 \mathrm{~Hz}$ tones (target) and $2000 \mathrm{~Hz}$ tones (standard) were randomly presented with probabilities of 0.2 and 0.8 .

We found P 300 as most consistent component of ERPs since childhood. P 300 latency and EMG-RT in children was significantly prolonged than in adults $(p<0.01)$. P 300 amplitude in children was significantly larger than in adults $(p<0.05)$. We concluded that both stimulus evaluation time and response selection time in children are more prolonged than that in adults, although ERPs is confirmed in children.
\end{abstract}

(Jpn. J. Phys. Fitness Sports Med. 2000, $49: 307 \sim 314$ )

kөy words : P 300, Event-related potentials (ERPs), EMG-RT, Children

\section{I. 緒}

各種運動の競技者は，小学校の時期から運動経 験を開始し，現在までに10年以上の長期的な運 動・トレーニングを行なってきたものが大半であ り，そのため，神経・筋系や心血管系，呼吸器系 において運動・スポーツ活動に対する適応状態が 形成されている．特に，骨格筋の肥大や筋線維組 成の変化 ${ }^{1)}$ 等が起こることがよく知られており, また心血管系や呼吸器系においては，スポーツ心 臓 ${ }^{2)}$ や最大酸素攝取量の増大等が挙げられる。ま た骨格筋を支配している運動神経や心臓，血管な どを支配している自律神経系は中枢神経系の支配 下にあることが今日明らかにされている。した
がって体育・スポーツ科学の研究領域において, ヒトの運動や行動に関して研究するためには，中 枢神経系について調べることが重要な課題である と考える.

ヒトの中枢神経系に関する研究には，脳波周 波数 (Electroencephalography frequency)を用い た研究が知られており，その他に事象関連電位 (Event-related Potentials : ERPs)，脳磁図 (Magnetoencephalography : MEG)，ポジトロン放 射断層撮影(Positron-emission tomography : PET) や筋電図反応時間 (Electromyogram reaction time : EMG-RT) 等が用いられている。その中でも ERPs は中枢内のより高次の認知, 情報処理過程 を実体的に評価する指標とされている，ERPs と
1) 筑波大学体育科学研究科 干305-8574 茨城県つくば市天王台1-1-

2) 筑波大学体育科学系 干305-8574 茨城県つくば市天王台1-1-1

3) 東京農工大学 于183-8506 東京都府中市幸町3-5-8
Doctoral Program in Health and Sports Sciences, University of Tsukuba, 1-1-1 Tennodai, Tsukuba-shi, Ibaraki 305-8574, Japan. Division of Physiology, Institute of Health and Sports Sciences, Univer-sity of Tsukuba, 1-1-1 Tennodai, Tsukuba-shi, Ibaraki 305-8574, Japan Division of Ecoregion Science, Faculty of Agriculture, Tokyo University of Agriculture and Technology, 3-5-8 Saiwai-cho, Fuchu 183-8509, Tokyo, Japan 
は, 被検者が呈示された種々の感覚刺激にかかわ る課題を行なった場合に頭皮上に誘発される電位 の総称であり, ヒトが外部からの情報を知覚し, それを処理したのち, 反応が生じるといった中枢 内で行なわれる情報処理過程に対応した大脳活動 を反映すると考えられている. ERPs 成分のうち, 特に刺激後 250 ～ $500 \mathrm{~ms}$ の間に出現する陽性波 はP 300 (P 3) と呼ばれており，1965年に Sutton

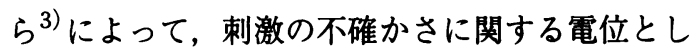
て初めて報告された。 また P 300 は刺激の識別が 困難である場合や難易度が増す場合にその潜時が 延長すること ${ }^{4)}$ ，刺激が被検者にとって意味を持 つ場合や被検者の注意・集中度が高い場合はその 振幅が増加すること ${ }^{5,6)}$ が報告されている。 これ らから, P 300 は中枢内で行なわれる情報処理過 程の中でも刺激の認知から刺激評価までの過程を 反映すると考えられている7 ${ }^{7,8)}$.

これまで P 300 潜時や振幅は，ヒトの加齢や発 達とともに変化する ${ }^{9,10)}$ という報告がなされて おり，Brown ら ${ }^{11)}$ や Picton ら ${ }^{12)}$ は, P 300 潜時 は成人から歳をとるにつれて加齢による影響から 延長していく ${ }^{13)}$ と報告している。 発達に関して は, Goodin ら ${ }^{14)}$ や榎 ${ }^{15)}$ が P 300 潜時は15, 16歳 を臨界点として, 発達とともに短縮する ${ }^{16)}$ と報 告している。しかしながら，小児期から小学校高 学年や思春期にかけての中枢神経系についての研 究では, 脳波周波数解析を用いた研究 ${ }^{17 \sim 19)}$ がな されているが, ERPs を指標とした認知機能に関

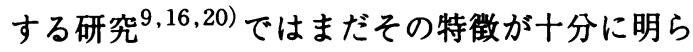
かにされていない。 それは，スキャモンの発育曲 線に示されるように，身長・体重・筋肉等が含ま れる一般型の変化とともに, 神経系の発達が思春
期までの間に急激に変化していく特徴があるため と考えられる，それゆえ，中枢神経系の発達を基 盤とするより高次の認知機能も，いくつかの段階 を経て，この時期に急激に変化していくことが考 えられる。

そこで本研究では, 中枢内の認知, 情報処理の 指標とされるERPs と, 反応に関わる情報処理の 指標とされる EMG-RT を用いて, 児童期の中枢 内で行なわれる情報処理過程の特徴について検討 することを目的とした。

\section{II. 方法}

\section{A. 対 象}

Table 1 は被検者となった児童・成人の身体的 特徵を示した. 被検者は神経疾患のない健康な览 童18名 $(9.3 \pm 1.5$ 歳), 成人12名 $(20.9 \pm 2.6$ 歳)で あり, 実験主旨を説明したうえで実験参加の同意 を得た. 被検者は $22 \sim 25^{\circ} \mathrm{C} に$ 空調されたシールド ルーム内の安楽椅子に腰掛け, 安静開眼状態でで きるだけ瞬きしないように指示した.

\section{B. 手 順}

最初に, 被検者は実験環境に慣れるために安静 座位, 開眼状態での安静脳波を 3 分間記録した。 続いてオドボール課題を用いて ERPs の測定を行 なった. 脳波及び ERPs は国際10-20法による Fz, $\mathrm{Cz}, \mathrm{Pz}, \mathrm{C} 3, \mathrm{C} 4$ の 5 部位から, 両耳架連結を 基準とし, $\mathrm{Ag} / \mathrm{AgCl}$ 電極を用いて単極導出した. また眼球運動 (EOG) も同時にモニタし, EEG と EOG を脳波計 (EE $1000 \mathrm{~A}, \mathrm{NEC})$ に紙記録し, 得 られたアナログデータは DAT テーブに記録し た.オドボール課題では, 被検者に $3 \sim 5$ 秒の間

Table 1. Characteristics of each group.

\begin{tabular}{cccccc}
\hline group & age & sex & dominant hand & height (cm) & weight (kg) \\
\hline $\begin{array}{c}\text { children } \\
\mathrm{n}=18\end{array}$ & $9.27 \pm 1.45$ & $\begin{array}{c}\text { male (10) } \\
\text { female (8) }\end{array}$ & $\begin{array}{r}\text { right (17) } \\
\text { left (1) }\end{array}$ & $135.95 \pm 9.79$ & $31.99 \pm 8.12$ \\
$\begin{array}{c}\text { adults } \\
\mathrm{n}=12\end{array}$ & $20.92 \pm 2.63$ & male (12) & right (12) & $169.54 \pm 5.36$ & $61.08 \pm 7.16$ \\
\hline
\end{tabular}

Values are Mean \pm SD. 
隔でヘッドホンから呈示される $1000 \mathrm{~Hz}$ と 2000 $\mathrm{Hz}$ の純音刺激 (duration : $50 \mathrm{~ms}$ plateau, rise/fall : $10 \mathrm{~ms}$ )が $2: 8$ の割合でランダムに与えられた. 被検者はそのうち $1000 \mathrm{~Hz}$ の音を識別した場合 に, なるべく早く利き腕の肘関節の伸展動作を行 ない, $2000 \mathrm{~Hz}$ の音は無視した。このとき, 被検 者の動作肢の上腕三頭筋より得られた筋電図 (EMG) を脳波計に紙記録し，得られたアナログデータは DAT テープに記録した。実験では，あらかじめ 被検者にこれらの 2 種類の音刺激を与えて, 音刺 激を十分に認識させ, 反応動作を行なわせた後, 課題を行なうよう指示した. 実験 diagramにつ いては Fig. 1 に示した.

\section{C. 記録・解析}

1. ERPs

ERPs 測定での bandpass filter は 0.15 100 Hz とした。記録時間は，児童のデータに関しては刺 激前 $200 \mathrm{~ms}$ から刺激後 $1000 \mathrm{~ms}$ までとし, 成人 のデータは刺激前 $200 \mathrm{~ms}$ から刺激後 $600 \mathrm{~ms}$ ま でとした. 解析は A/D 変換したデー夕を $250 \mathrm{~Hz}$ のサンプリング周波数で, 波形解析ソフト (EPLIZER，キッセイコムテック)を用いて行なっ
た. 解析処理において, $\pm 100 \mu \mathrm{V}$ 以上の $\mathrm{EOG}$ が出現した試行を除き， $1000 \mathrm{~Hz}$ の音刺激をトリ ガーとして 12 20試行分を加算平均し ${ }^{20)}, \mathrm{ERP}$ 波形を求めた。そして誘発された波形と極性から P 300 (刺激後 250 500 m s に生じる最大陽性電 位)を同定し, 潜時と振幅の測定を行った。また 潜時は刺激点から頂点までの時間とし, 振幅は刺 激前 $100 \mathrm{~ms}$ から刺激点までの平均電位を基線と し, 基線からその頂点までの值とした。

\section{EMG-RT}

EMG は，表面双極導出法により上腕三頭筋に 約 $3 \mathrm{~cm}$ 間隔で電極を装着した. bandpass filter は $0.05 \sim 1500 \mathrm{~Hz}$ とした. EMG-RTは, 刺激点 から P 300 加算時に記録した EMG 原波形の EMG onset までを測定し，その平均値を被検者 個々の EMG-RT として用いた.

\section{D. 統計処理}

P 300 の潜時・振幅に関しては, 年齢群 (児童 ・ 成人) と記録部位 $(\mathrm{Fz} \cdot \mathrm{Cz} \cdot \mathrm{Pz} \cdot \mathrm{C} 3 \cdot \mathrm{C} 4)$ の二元 配置の分散分析を行い, 各水準間で有意差が見ら れた場合に，下位検定を行なった。また EMG-RT については年齢群により, t-test : Un-

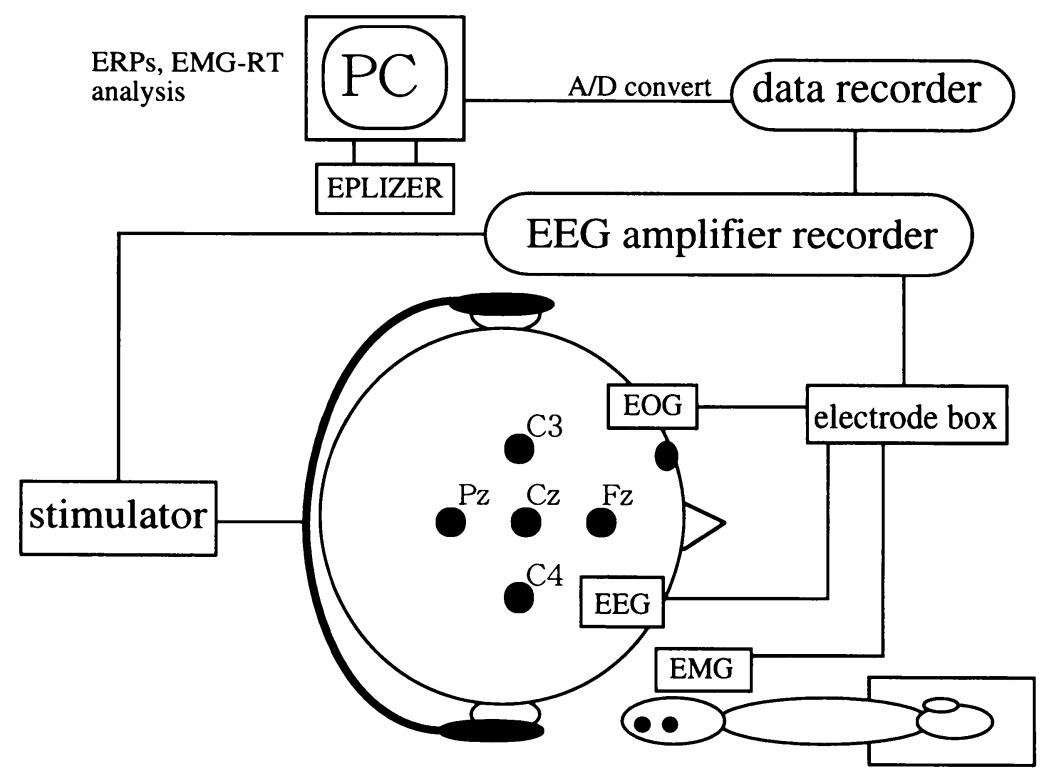

Fig. 1. Block diagram of experiment and analysis. 
paired を行なった，有意差検定での有意水準は $5 \%$ 末満とした。

\section{III. 結 果}

\section{A. 波 形}

Fig. 2 は, 児童と成人の被検者の総加算平均し た ERPs の波形を示している．本研究では全ての 被検者において, P 300 を確認できた.また, P 300 の出現前に注意に関連するといわれる N 100 P $\mathrm{P}$ 200, N 200 に相当する頂点を確認することがで きた.

\section{B. P 300 成分}

児童の P 300 潜時は, 成人と比較して年龄群間 に有意差が見られ，览童から得られた潜時が有意 に遅かったが，部位間には有意差が見られなかっ
た(Table 2).

また览童の P 300 振幅は, 成人と比較して年齢 群間・部位間ともに有意差が見られ, 部位ごとに みた結果, 全ての部位で有意に大きな值を示した (Table 3).ささらにP 300 振幅の頭皮上分布を検 討した結果, P 300 振幅は頭頂部 $(\mathrm{Pz})$ 優位に出現 し, 児童と成人のどちらにおいても, $\mathrm{Pz}$ の值が 他の部位 $(\mathrm{Fz}, \mathrm{Cz}, \mathrm{C} 3, \mathrm{C} 4)$ と比べて有意に大き かった(Table 3).

\section{EMG-RT}

児童, 成人のどちらにおいても，標的刺激に対 して,ほほ全試行でEMG がみられた. Fig. 2 に は, 得られた EMGの一例を示した. EMG-RT は, P 300 の加算に用いた試行から得られた值を平均 化したものであった。 その結果，巟童の EMG-

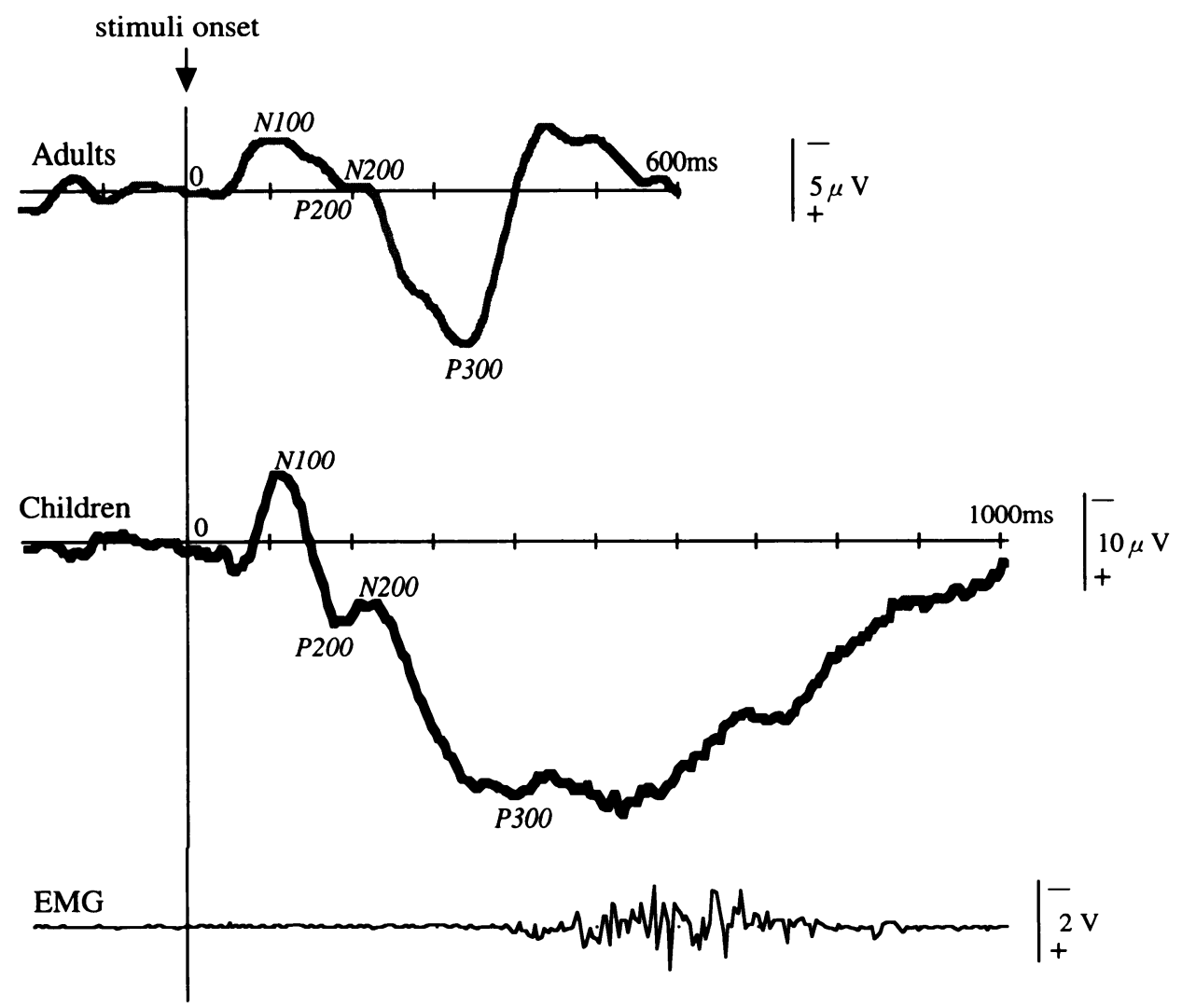

Fig. 2. Grand average of ERPs at children and adults, and EMG in one child. P 300 was identified. 
Table 2. Mean $\mathrm{P} 300$ latencies with standard deviations at all sites $(\mathrm{Fz}, \mathrm{Cz}, \mathrm{Pz}, \mathrm{C} 3$ and C 4) from stimuli onsets between children and adults.

\begin{tabular}{llll}
\hline & children & adults \\
\hline P300 latency $(\mathrm{msec})$ & & $324.20 \pm 29.95$ & $* *$ \\
\hline average at all electrode times & $379.80 \pm 65.13$ & & \\
\hline
\end{tabular}

Values are Mean \pm SD.

** indicates a signifcant difference between children and adults at $\mathrm{p}<0.01$.

Table 3. Mean P 300 amplitudes with standard deviations at $\mathrm{Fz}, \mathrm{Cz}, \mathrm{Pz}, \mathrm{C} 3$ and $\mathrm{C} 4$ from the smoothed baseline to peak measurement between children and adults.

\begin{tabular}{|c|c|c|c|c|c|c|}
\hline & \multicolumn{3}{|c|}{ children } & \multicolumn{2}{|l|}{ adults } & \\
\hline \multicolumn{7}{|c|}{ P300 amplitude $(\mu \mathrm{V})$} \\
\hline $\mathrm{Fz}$ & 19.60 & \pm 11.38 & & $8.01 \pm 4.97$ & & $*$ \\
\hline $\mathrm{Cz}$ & 21.45 & \pm 9.93 & & $7.04 \pm 4.65$ & & $* *$ \\
\hline $\mathrm{Pz}$ & 32.61 & \pm 9.96 & \# \# & $11.91 \pm 4.50$ & $\# \#$ & $* *$ \\
\hline $\mathrm{C} 3$ & 22.39 & \pm 10.58 & & $7.24 \pm 3.66$ & & $* *$ \\
\hline $\mathrm{C} 4$ & 18.25 & \pm 8.17 & & $8.15 \pm 3.67$ & & $* *$ \\
\hline
\end{tabular}

Values are Mean \pm SD.

$*, * *$ indicates a signifcant difference between children and adults at $p<0.05, p<0.01$.

\#\# indicates a signifcant difference among 5 sites $(\mathrm{Fz}, \mathrm{Cz}, \mathrm{Pz}, \mathrm{C} 3, \mathrm{C} 4)$ at $\mathrm{p}<0.01$.

Table 4. EMG-RT from stimuli onsets between children and adults.

\begin{tabular}{llcl}
\hline & children & \multicolumn{1}{c}{ adults } \\
\cline { 2 - 3 } EMG-RT (msec) & $385.27 \pm 121.22$ & $274.58 \pm 48.57$ & $* *$ \\
\hline
\end{tabular}

Values are Mean \pm SD.

** indicates a signifcant difference between children and adults at $\mathrm{p}<0.01$.

RT は, 成人と比較して, 有意に遅い値を示した (Table 4).

\section{N.}

本研究では, ERPs の中のP 300 成分と EMG-RT を指標として，児童の中枢内で行なわ れる情報処理過程の特徴を明らかにすることを目 的とした。

\section{A. 波 形}

本研究では，児童・成人の被検者それぞれから 得られた加算平均波形から全被検者で P 300 を確 認できた ${ }^{21,22)}$ 。また，P 300 に先行して出現す る注意に関連するといわれる N 100 や P 200, N 200 に相当する成分 ${ }^{23)}$ を同様に確認できた。 ERPs 波形の中には, P 300 以外にもいくつかの 成分が認められており，N 100 成分は注意に関連 する陰性電位 ${ }^{24)}$ と考えられ，そのため N 100 に 
相当する成分がみられたことから，児童において も選択的注意機能が適切にはたらいていると推測 することができる。また N 200 成分は与えられ ている課題を遂行するために, 被検者が積極的に 行っている刺激のカテゴリー知覚・カテゴリー認 識に関連する電位といわれている ${ }^{24)}$ 。そこで児 童の ERPs 波形において, 成人とほほ同様の波形 がみられたことに加えて，P 300 のみならずその 他の電位成分がみられたことから, 中枢内の一連 の情報処理に関わる機能が，览童期においてすで に現われているものと考えられる.

\section{B. $P 300$ 成分}

\section{1. 潜 時}

本研究において, 児童の P 300 潜時は, 成人と 比較して, 有意に遅い値を示した.Kutas ら ${ }^{7)}$ は P 300 潜時は刺激に対する刺激評価過程を，また Magliero $~^{8)}$ は反応選択や実行から独立する刺激 評価過程の時間的指標として用いることができる

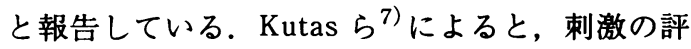
価を完全に終えてから反応する場合の反応時間と P 300 潜時では高い相関が得られるのに対し, 刺 激の評価が不完全なままの状態，つまりできるだ け早く反応することに重点をおいた状態で刺激に 対する反応を開始した場合の反応時間と P 300 潜 時では相関が低くなるため, 中枢内で行なわれる 課題に対する反応選択・実行過程と P 300 が反映 する過程が異なると述べており，そのためP 300 によって示される処理過程は, 刺激評価に関わる 過程であるとしている．さらに，P 300 潜時は刺 激の識別が困難な場合に延長する報告がある ${ }^{4)}$.

また発達や加齢に関する研究において, Brown $ら^{11)}$ や Picton $ら^{12)}$, Pfefferbaum $ら^{13)}$ は, 成人 を過ぎると加龊とともに P 300 潜時は延長してい くと述べており, Goodin ら ${ }^{14)}$ や榎 $^{15)}$ は P 300 潜 時は発達によって短縮し，15，16歳で最短になる と報告している。この P 300 潜時の発達による変 化について, Goodin $ら^{14)}$, Courchesne ${ }^{25)}$ は, 中 枢神経系の髄鞘化に関連するものとして説明して いる.P 300 の起源については, 海馬 ${ }^{26,27)}$ や視 床 $^{28)}$ などの関与が示唆されているが, Yakovlev
と Lecours ${ }^{29)}$ によると, 補足運動野を含む網様体, 海馬, 視床の一部, 終脳の白質では, その娟鞘形 成の完成は10歳以降であるとされている，また, 脳の機能的側面を䯣鞘化よりもょりょく反映する といわれるシナプス形成は樹状突起の発達と相互 に関連しあうとされている ${ }^{30)}$ が, 他の部位と比 較して連合野ではその発達が遅く, 前頭連合野の シナプス密度は 15 歳頃に成人值に達するという報 告 ${ }^{31)}$ がある.これらのことから, 本研究で対象 とした児童は 7 １2歳であり，身体的変化だけで なく，中枢神経系の働きに関わる部位においても その完成までの発達段階であるために，中枢神経 系も大きな変化を遂げている時期にあたると考え られる。 また脳の可塑性の変化は発達時期の脳で 最も顕著であるため, 本研究における児童におい ても外部から受ける多くの情報や刺激によって起 こる中枢神経系での変化が成人に至るまでの過程 において大きいと考えられる，その結果，児童期 では刺激評価に関わるとされる P 300 潜時が成人 と比較して遅くなることが考えられる。

\section{2. 振 幅}

本研究における P 300 振幅は, 成人と比較して, 览童では有意に高い振幅が得られた。 ERPs の振 幅に関して，一般に成長にともない, ヒトの頭蓋 骨, 皮下組織は肥厚する傾向にあるが, これに伴 い頭皮電極と脳表の間のインピーダンスは増大 し，振幅は低下するものと推察される ${ }^{33)}$. その ため本研究における児童のP 300 振幅の結果は, この成長による振幅の変化の影響を受け, 成人の 值よりも大きい值を示したことが考えられる.

さらに, 先行研究において, P 300 振幅は記憶 更新時の課題に対する処理資源の分配量に依存 し ${ }^{32)}$ ，被検者の精神状態によって大きく左右さ れる ${ }^{5,6)}$ という報告がなされている。 また P 300 振幅の発達による変化に関する研究では, 個人差 が大きく，一定の傾向が認められない ${ }^{14,16)}$ とす る報告が多く，年齢との相関関係が低いとされ， この点に関して十分にわかっていない. その理由 として, P 300 振幅それ自体個人差が大きいこと と, 対象個々の課題に対する注意の程度にばらつ きが大きいなどの要因が考えられている，そこで 
本研究の児童の内省報告をみてみると,「楽しかっ た，面白かった」等の報告が非常に多くみられ， 児童は課題に対して非常に多くの処理資源を分配 していたことが予想される。

\section{3. 頭皮上分布}

P 300 振幅の頭皮上分布は，成人，児童のどち らにおいても，頭頂部 $(\mathrm{Pz})$ が他の 4 部位よりも 有意に大きな値を示した．頭頂部 $(\mathrm{Pz})$ は，大脳 皮質の頭頂葉に当たる．頭頂葉は，中心溝から後 ろの部分で, 一次感覚野や感覚の連合野に当たる 部分であり，この頭頂葉の連合野は知覚及び空間 の認知に基づく思考に関する統合を行なってい る.すなわち頭頂葉連合野は聴覚野や体性感覚野, 視覚野などからの感覚情報が記憶され，あるいは すでにある記憶と照合され，認知し，理解し，判 断されるといった高次の情報処理過程及びその過 程の操作に関わっている ${ }^{34,35)}$ と考えられる. 本 研究の結果は, P 300 振幅の頭皮上分布に関する 報告 ${ }^{14,25)}$ と同様に，览童においても，頭頂部優 位であった。このことから，巟童期においても， 高次の情報処理に関わっているとされる頭頂葉連 合野が, 成人と同様に働いていると推測すること ができる。

\section{EMG-RT}

EMG は被検者全員で確認された。しかし児童 の EMG-RT は被検者内においても一試行ごとに かなりのばらつきがみられた。本研究から得られ た EMG-RT は，成人の值と比較して，有意に延 長していた。これはP 300 潜時と同様に児童期で は，中枢内の認知情報処理に関わる中枢部位が完 成まで至っていないため, 刺激処理過程と並んで, 反応実行過程を反映すると考えられている7) EMG-RT も成人と比較するとかなり延長したと 考えられる。

\section{V. 結 語}

本研究では, 児童の中枢内で行なわれる情報処 理過程の特徴について, 中枢内の認知, 情報処理 の指標とされる ERPs, EMG-RT を指標に用いて, 明らかにすることを目的とした。
結果は, 以下の通りである.

児童の ERPs 波形, P 300 潜時 - 振幅, 頭皮上 分布に関する検討から，児童においても，成人と 同様に中枢内の認知，情報処理過程が存在すると 考えられる。しかしながら児童期では，その完成 は十分ではなく，発達による変化の過程にあると 考えられる．また EMG-RT が成人と比較して児 童において遅いことから，P 300 潜時が反映する であろう刺激処理過程と同様に, 反応処理過程も 児童期では完成に至っていないと考えられる。

\section{（受理日 平成12年 1 月 20 日）}

\section{文}

1) Andersen, P. and Henriksson, J. Capillary supply of the quadriceps femoris muscle of man : adaptive response to exercise. J. Physiol., (1977), 270, 677-690.

2) Huston, T. P., Puffer, J. C. and Rodney, W. M. The athletic heart syndrome. N. Engl. J. Med., (1985), 313, 24-32

3) Sutton, S., Braren, M. and Zubin, J. Evokedpotential correlates of stimulus uncertainty. Science, (1965), 150(26), 1187-1188.

4) Goodin, D. S., Squires, K. C. and Starr, A. Variations in early and late event-related com. ponent of the auditory evoked potential with task difficulty. Electroenceph. clin. Neurophysiol., (1983) , 55, 680-686.

5) Campbell, K. B., Courchesne, E., Picton, T. W. and Squires, K. C. Evoked potential correlates of human information processing. Biol. Psychol., (1979), 8, $45-$

68.

6) McCarthy, G., Wood, C. C., Williamson, P. D. and Spencer, D. D. Task-dependent field potentials in human hippocampal formation. Journal of Neuroscience, (1989), 9(12), 4253-4268.

7) Kutas, M., MaCarthy, G. and Donchin, E. Augmenting mental chronometry: The P 300 as a measurement of stimulus evaluation time. Science, (1977). 197. 792-795.

8) Magliero, A., Bashore, T. R., Coles, M. G. H. and Donchin, E. On the dependence of P 300 latency on stimulus evaluation Processes. Psychophysiology, (1984), 21 (2), 171-186.

9) Martin, L., Barajas, J. J., Fernandez, R. and Torres, E. Auditory event-related potentials in wellcharacterized groups of children. Electroenceph. clin. Neurophysiol., (1988), 71 (5), 375-381.

10）音成隆司, Barrett, G., 柴崎浩. 大脳誘発電位後期 陽性成分 (P 300) の正常所見及び加齢の影響. 脳波 と筋電図，(1986)，14(3)，177-183. 
11) Brown, W. S., Marsh, J. T. and LaRue, A. Exponential electrophysiological aging: P 3 latency. Electroenceph. clin. Neurophysiol., (1984), 55(3), 277285.

12) Picton, T. W., Stuss, D. T., Champagne, S. C. and Nelson, R. F. The effects of age on human eventrelated potentials. Psychophysiology, (1984), 21 (3), 312-25.

13) Pfefferbaum, A., Ford, J. M., Wenegrat, B. G., Roth, W. T. and Kopell, B. S. Clinical application of the P 3 component of event-related potentials. I. Normal aging. Electroenceph. clin. Neurophysiol., (1984), 59 (2), 85-103.

14) Goodin, D. S., Squires, K. C., Henderson, B. H. and Starr, A. Age-related variations in evoked potentials to auditory stimuli in normal human subjects. Electroenceph. clin. Neurophysiol., (1978), 44, 447458 .

15）榎日出夫. 事象関連電位 P 300 の発達及び加齡に 伴う変動に関する研究. 脳波と筋電図, (1990), 18 (1), 60-67.

16）佐藤隆美, 澤立子, 宮尾益知, 清水夏絵, 二瓶一夫, 鴨下重彦．小巟における P 300 の検討. 脳と発達, (1990)，18，373-379.

17）尾崎久記. 脳波基碟リズムの発達（I）脳波周波 数及び成分の優势部位. 臨床脳波，(1994），36(2)， 123-126.

18) Walter, W. G. Chapt. VII in Hill and Parr, (ed) Electroencephalography. Ist editition, Mac Donald, London, (1950)

19）吉田治美. 脳波等電位図法による小児脳波の発達 に関する研究. 脳波と筋電図, (1984), 12(4), 248260.

20）藤川貞敏，大府正治，藤川麻衣子，満留昭久，小 児 ( 8 ～14歳)の事象関連電位 P 300 の加算回数に 関する研究. 脳波と筋電図, (1995), 23(4), 389394.

21）日本脳波 - 筋電図学会. 誘発電位測定指針 (1997年 改訂)。脳波と筋電図，(1998)，26(2)，185-200.

22）下河内稔，投石保広，楊井一彦，小山幸子. P 300 の基礎．神経進歩，(1988)，32(1)，149-162.
23）投石保広，下河内稳. 内因性 ERP の成分同定と主 成分分析. 臨床脳波, (1984)，26(10)，623-628.

24）下地恒毅. 誘発電位. 西村書店, 新潟, (1992)，152168.

25) Courchesne, E. Neurophysiological correlates of cognitive development : changes in long-latency event-related potentials from childhood to adult hood. Electroenceph. clin. Neurophysiol., (1978), 45 (4), 468-482.

26) Halgren, E., Squires, N. K., Wilson, C. L., Rohr baugh, J. W., Babb, T. L. and Crandall, P. H. En dogenous potentials generated in the human hippocampal formation and amygdala by infrequent events. Science, (1980), 210, 803-805.

27) Okada, Y. C., Kaufman, L. and Williamson, S. J. The hippocampal formation as a source of the slow endogenous potentials. Electroenceph. clin. Neurophysiol., (1983), 55(4), 417-26.

28) Yingling, C. D. and Hosobuchi, Y. A subcortical correlate of $P 300$ in man. Electroenceph. clin. Neurophysiol., (1984), 59(1), 72-76

29) Yakovlev, P. I. and Lecours, A. R. The myelogenetic cycles of regional maturation of the brain, In mink owski A (ed) : Resional Development of the Brain in Early Life. Blackwell, Oxford, (1967), 3-70.

30) Holmes, G. L. Morphological and physiological maturation of the brain in the neonate and child. $J$. Clin. Neurophysiol., (1986), 3, 209-238.

31) Huttenlocher, P. R. Synaptic density in human frontal cortex : Developmental changes and effect of ag ing. Brain Res., (1979), 163, 195-205.

32) Picton, T. W. The P 300 wave of the human eventrelated potential. J. Clin. Neurophysiol., (1992), 9 (4), 456-479.

33）小川和則. 運動関連脳電位の年龄発達に伴う変化 に関する研究. 脳波と筋電図, (1996)，24(4)，260267.

34）真島英信. 生理学. 文光堂, 東京, (1990)，175202.

35）田代信維. 脳一その構造と機能. 世界保健通信社, 大阪，(1993），120-135 